\title{
Upaya Peningkatan Hasil Belajar Biologi Materi Pokok Keunikan Hutan Hujan Tropis Melalui Penerapan Metode Eksperimen
}

\author{
Desak Nyoman Puspayani \\ SMA Negeri 1 Sukawati \\ e-mail: Puspayani345@gmail.co.id
}

\begin{abstract}
Abstrak
Adapun tujuan penelitian ini adalah untuk mengetahui peningkatan pencapaian hasil belajar biologi dengan materi keunikan hutan-hutan tropis, bagi siswa kelas $X$ semester I SMA Negeri 1 Sukawati tahun pelajaran 2016/2017. Penelitian ini dilakukan di SMA Negeri 1 Sukawati dengan jumlah siswa 30 orang. Penelitian ini dilakukan dalam dua siklus, tiap siklus dalam penelitian meliputi empat langkah yaitu (1) perencanaan (planning), (2) pelaksanaan (acting), (3) observasi (observing), (4) refleksi (reflecting). Data hasil belajar siswa dikumpulkan dengan tes hasil belajar Biologi. Analisis data yang digunakan pada penelitian ini adalah analisis deskriptif kuantitatif. Hasil yang dicapai dalam penelitian ini adalah rata-rata hasil belajar siswa pada siklus I sebesar 78 sedangkan pada siklus II meningkat menjadi 83. Berdasarkan hasil tersebut, dapat disimpulkan bahwa: dengan menerapkan metode eksperimen dalam pembelajaran biologi dapat meningkatkan hasil belajar siswa kelas $\mathrm{X}$ Semester I SMA Negeri 1 Sukawati secara signifikan.
\end{abstract}

Kata Kunci : Hasil Belajar Biologi, Keunikan hutan - hutan Tropis, Metode Eksperimen.

\section{Abstract}

The purpose of this study was to determine the increase in achievement of learning outcomes of biology with the material uniqueness of tropical forests, for class $X$ students in semester I of SMA Negeri 1 Sukawati in the academic year 2016/2017. This research was conducted in Sukawati 1 Public High School with 30 students. This research was conducted in two cycles, each cycle in the study included four steps, namely (1) planning, (2) implementation, (3) observation, (4) reflection. Student learning outcomes data were collected by Biology learning outcomes tests. Data analysis used in this study is quantitative descriptive analysis. The results achieved in this study are the average student learning outcomes in the first cycle of 78 while in the second cycle increased to 83. Based on these results, it can be concluded that: by applying the experimental method in biology learning can improve student learning outcomes in class X Semester I Sukawati 1 Public High School significantly.

Keywords: Biological Learning Outcomes, Uniqueness of Tropical Forests, Experimental Method. 


\section{Pendahuluan}

Pendidikan merupakan suatu proses yang diperlukan untuk mendapatkan keseimbangan dan kesempurnaan dalam perkembangan individu maupun masyarakat. Penekanan pendidikan dibanding dengan pengajaran terletak pada pembentukan kesadaran dan kepribadian individu atau masyarakat di samping transfer ilmu dan keahlian. Dengan proses semacam ini suatu bangsa atau negara dapat mewariskan nilai-nilai keagamaan, kebudayaan, pemikiran dan keahlian kepada generasi berikutnya, sehingga mereka betul-betul siap menyongsong masa depan kehidupan bangsa dan negara yang lebih cerah (Nurkholis ,2013).

Pendidikan nasional telah diatur dan didefinisikan dalam Undang-Undang Sistem Pendidikan Nasional (UU Sisdiknas) nomor 20 tahun 2003. Dalam UU tersebut pendidikan didefinisikan sebagai usaha sadar dan terencana untuk mewujudkan suasana belajar dan proses pendidikan agar siswa secara aktif mengembangkan potensi dirinya untuk memiliki kekuatan spiritual keagamaan, pengendalian diri, kepribadian, kecerdasan, akhlak mulia, serta keterampilan yang diperlukan dirinya, masyarakat, bangsa dan Negara (Hidayat ,2017).

Pendidikan dapat juga diartikan sebagai pembelajaran yang diselenggarakan di sekolah sebagai lembaga pendidikan formal. Dimana misi pendidikan sendiri adalah untuk mencerdaskan kehidupan bangsa dan mengembangkan kualitas manusia seutuhnya. hal tersebut dapat diartikan bahwa pendidikan memegang peranan yang sangat penting dalam perkembangan bangsa. Pendidikan yang mampu memfasilitasi perkembangan bangsa salah satunya adalah pendidikan yang bermutu. Pendidikan yang bermutu sendiri sangat ditentukan pula oleh penyelenggaraan proses pembelajaran yang berkualitas dan memberdayakan siswa. Pembelajaran yang berkualitas adalah pembelajaran yang berpusat pada siswa (Student Centred), yaitu yang memberdayakan kemampuan siswa. Hal ini sesuai dengan pandangan pembelajaran dengan konstruktivistik yang artinya siswalah yang membangun pengetahuan mereka sendiri dan siswa dituntut aktif terlibat dalam kegiatan pembelajaran, sehingga dapat menemukan konsep pengetahuan yang bermakna bagi kehidupannya. Sejalan dengan itu pembelajaran biologi mempunyai karakteristik yang berbeda dengan ilmu lainnya baik dalam hal objek, persoalan dan metode yang bisa diterapkan oleh guru untuk menunjang pembelajaran biologi.

Biologi sebagai salah satu bidang IPA menyediakan berbagai pengalaman untuk memahami konsep dan proses sains. Keterampilan proses ini menjadi keterampilan mengamati, mengajukan hipotesis, menggunakan alat dan bahan secara baik dan selalu mempertimbangkan keamanan dan keselamatan kerja, mengajukan pertanyaan, membuat hipotesis,menggolongkan dan menafsirkan data, serta mengkomunikasikan hasil eksperimen secara lisan atau tulisan, menggali dan memilah informasi faktual dan relevan untuk menguji gagasan-gagasan atau memecahkan masalah dalam kehidupan sehari-hari. Mata pelajaran Biologi dikembangkan melalui kemampuan berpikir analitis, induktif, dan deduktif untuk menyelesaikan masalah yang berkaitan dengan peristiwa alam sekitar. Penyelesaian masalah yang bersifat kualitatif dan kuantitatif dilakukan dengan menggunakan pemahaman dalam bidang matematika, fisika, kimia dan pengetahuan pendukung lainnya. Seperti telah diuraikan bahwa pembelajaran biologi idealnya sesuai dengan hakikatnya sebagai sains yaitu setidaknya mengacu 3 hal yaitu: proses, produk, sikap. Pembelajaran biologi idealnya memungkinkan peserta didik melakukan serangkaian keterampilan proses sains mulai dari mengamati, mengelompokkan (klasifikasi), mengukur, menghitung, meramalkan, mengkomunikasikan, mengajukan pertanyaan (bertanya), menyimpulkan, mengontrol variabel, merumuskan masalah, membuat hipotesis, merancang penyelidikan, melakukan penyelidikan/ percobaan. Setelah melakukan serangkaian keterampilan proses, peserta didik akan mengkonstruk konsep-konsep materi biologi (Sudarisman , 2015). Pendidikan memegang peranan penting dalam mempersiapkan sumber daya manusia yang berkualitas. Oleh karena itu, pendidikan hendaknya dikelola, baik secara kualitas maupun kuantitas. Hal tersebut bisa tercapai bila pelajar dapat menyelesaikan pendidikan tepat pada waktunya dengan hasil belajar yang baik. Hasil belajar seseorang ditentukan oleh berbagai faktor yang mempengaruhinya. Salah satu faktor yang ada di luar individu adalah tersedianya bahan ajar yang memberi kemudahan bagi individu untuk mempelajarinya, sehingga menghasilkan belajar yang lebih baik. Belajar mengajar adalah suatu kegiatan yang bernilai edukatif (Rahmayanti ,2016).

Seorang guru biologi perlu menguasai pengetahuan, cara kerja dan keterampilan dalam bidangnya. Guru biologi di SMA perlu menguasai biologi secara mendalam, metode-metode biologi, dan keterampilan-keterampilan dasar biologi. Biologi merupakan ilmu yang sudah cukup tua, karena sebagian besar berasal dari keingin tahuan manusia tentang dirinya, 
lingkungannya, dan tentang kelangsungan hidup jenisnya. Biologi dimasukkan ke dalam ilmuilmu yang mengkaji tentang manusia dan makhluk hidup lainnya. Namun, biologi juga termasuk ilmu-ilmu yang mengkaji tentang alam seperti halnya dengan astronomi, geologi, fisika dan kimia. Unik dan khasnya, biologi membaur dalam kedua kelompok studi yang berbeda tersebut (Rustaman, 2003:13-15). Pembelajaran biologi bertujuan untuk memberikan pemahaman kepada siswa agar memiliki kemampuan sebagai berikut: a) Membentuk sikap positif terhadap biologi dengan menyadari keteraturan dan keindahan alam serta mengagungkan kebesaran Tuhan Yang Maha Esa, b) Memupuk sikap ilmiah yaitu jujur, objektif, terbuka, ulet, kritis dan dapat bekerjasama dengan orang lain, c) Mengembangkan pengalaman untuk dapat mengajukan dan menguji hipotesis melalui percobaan, serta mengkomunikasikan hasil percobaan secara lisan dan tertulis, d) Mengembangkan kemampuan berpikir analitis, induktif, dan deduktif dengan menggunakan konsep dan prinsip biologi, e) Mengembangkan penguasaan konsep dan prinsip biologi dan saling keterkaitannya dengan IPA lainnya serta mengembangkan pengetahuan, keterampilan dan sikap percaya diri, f) Menerapkan konsep dan prinsip biologi untuk menghasilkan karya teknologi sederhana yang berkaitan dengan kebutuhan manusia, dan g) Meningkatkan kesadaran dan berperan serta dalam menjaga kelestarian lingkungan.

Berdasarkan pengamatan awal yang dilaksanakan peneliti terhadap proses pembelajaran mata pelajaran biologi di kelas X Semester I SMA Negeri 1 Sukawati terdapat data dan informasi bahwa hasil belajar yang dicapai siswa belum mencapai nilai standar yang ditentukan sekolah yaitu 78 . Sedangkan hasil prasiklus yang dicapai siswa dengan nilai ratarata 73 dengan ketuntasan belajar mencapai $43 \%$.

Rendahnya hasil belajar siswa, atau belum terwujudnya keterampilan proses dan pembelajaran yang menekankan pada peran aktif siswa, adalah salah satu kurangnya kemampuan siswa dalam memaknai konsep materi pelajaran biologi tentang keunikan hutan hutan tropis. Rendahnya hasil penilaian mata pelajaran biologi menunjukkan rendahnya motivasi belajar siswa karena pembelajaran biologi kurang menarik. Metode pembelajaran yang digunakan guru hanya menghafalkan suatu konsep sehingga siswa merasa bosan dan kurang berkonsentrasi dalam belajar (Garnasih ,2018).

Materi-materi biologi sering dipandang siswa sebagai materi yang sulit dipelajari. Beberapa hal yang menyebabkan materi biologi sulit bagi siswa menurut Cimer (2012) sebagai berikut. (1). Karakteristik tiap materi biologi.Materi biologi memiliki konsep dan permasalahan kompleks yang harus dipelajari oleh siswa. Selain itu banyak objek biologi yang tidak dapat diamati secara langsung, bersifat abstrak, banyak menggunakan istilah asing/ latin. (2). Strategi pembelajaran yang disajikan oleh guru.Banyak guru yang masih menggunakan pembelajaran ceramah yang berpusat pada guru dan tidak mengaitkan dengan kehidupan sehari-hari. Hal ini menyebabkan siswa sulit memahami materi dan tidak termotivasi untuk mempelajari biologi lebih lanjut. (3). Kurangnya penguasaan guru.Guru hanya mentransfer pengetahuan yang terdapat pada buku pegangan. Guru tidak dapat mengembangkan materi yang disajikan dalam buku pegangan, sehingga siswa tidak tertarik terhadap materi yang disampaikan oleh guru. (4). Kebiasaan siswa belajar. Banyak siswa yang tidak rutin mempelajari materi biologi dan tidak mempelajari kembali materi yang telah diajarkan di kelas. (5). Kurangnya fasilitas pembelajaran. Ada beberapa sekolah yang tidak memiliki laboratorium, sehingga siswa tidak dapat melakukan kegiatan pengamatan maupun kegiatan eksperimen. (6). Kurangnya waktu pembelajaran. Materi biologi terdiri dari konsep dan permasalahan yang kompleks. Hal ini dirasa tidak imbang oleh siswa ketika siswa diminta mempelajarinnya dengan alokasi waktu yang sedikit/ terbatas (Alfi ,2018).

Oleh karena itu guru perlu melakukan nperbaikan n-perbaikan dengan menerapkan metode belajar yang tepat dalam pembelajaran biologi dengan menggunakan metode eksperimen. Eksperimen menurut Kerlinger (1986: 315) adalah sebagai suatu penelitian ilmiah dimana peneliti memanipulasi dan mengontrol satu atau lebih variabel bebas dan melakukan pengamatan terhadap variabel-variabel terikat untuk menemukan variasi yang muncul bersamaan dengan manipulasi terhadap variabel bebas tersebut. Arboleda (1981: 27) mendefinisikan eksperimen sebagai suatu penelitian yang dengan sengaja peneliti melakukan manipulasi terhadap satu atau lebih variabel dengan suatu cara tertentu sehungga berpengaruh pada satu atau lebih variabel lain yang di ukur. Lebih lanjut dijelaskan, variabel yang dimanipulasi disebut variabel bebas dan variabel yang yang akan dilihat pengaruhnya disebut variabel terikat. Sementra itu Isaac dan Michael (1977: 24) menerangkan bahwa penelitian Eksperimen bertujuan untuk meneliti kemungkinan sebab akibat dengan mengenakan satu atau lebih kondisi perlakuan pada satu atau lebih kelompok eksperimen dan membandingkan 
hasilnya dengan satu atau lebih kelompok kontrol yang tidak diberi perlakuan. Pengertian yang hampir sama dengan itu diberikan oleh Rakhmat (1985: 44) bahwa metode eksperimen bertujuan untuk meneliti hubungan sebab akibat dengan memanipulasikan satu atau lebih variabel pada satu atau lebih kelompok eksperimen dan membandingkan hasilnya dengan kelompok kontrol yang tidak mengalami manipulasi. Sedangkan Robert Plutchik (1988: 213) mengemukakan definisi eksperimen secara lebih singkat, adalah merupakan cara mengatur kondisi suatu esperimen untuk mengidentifikasi variabelvariabel dan menentukan sebab akibat suatu kejadian (Setyanto ,2015).

Berkaitan dengan hal tersebut diatas maka dalam pelaksanaan Penelitian Tindakan Kelas ini Peneliti mengangkat mata pelajaran biologi sesuai yang diajarkan oleh Peneliti yang menitik beratkan pada materi tentang keunikan hutan-hutan tropis. Maka judul Penelitian Tindakan Kelas ini adalah "Upaya Meningkatkan Hasil Belajar Biologi Materi Keunikan HutanHujan Tropis Melalui Penerapan Metode Eksperimen Bagi Siswa Kelas X Semester I Sma Negeri 1 Sukawati Tahun Pelajaran 2016/2017".

\section{Metode}

Penelitian ini dilakukan pada semester satu tahun pelajaran 2016/2017 di Kelas X. Semester I SMA Negeri 1 Sukawati. Penelitian mulai dari Perencanaan sampai dengan penulisan laporan hasil penelitian tersebut mulai dari bulan Julis.d Desember Tahun 2016. Subyek Penelitian ini adalah siswa kelas $X$ semester I SMA Negeri 1 Sukawati yang berjumlah 30 orang. Adapun objek dalam penelitian ini adalah upaya peningkatan hasil belajar biologi materi pokok keunikan hutan hujan tropis melalui penerapan metode eksperimen.

Penelitian Tindakan Kelas ini target Penelitian telah tercapai sesuai dengan rencana. Adapun bagan dari prosedur Penelitian ini dapat disampaikan sebagai bereikut :

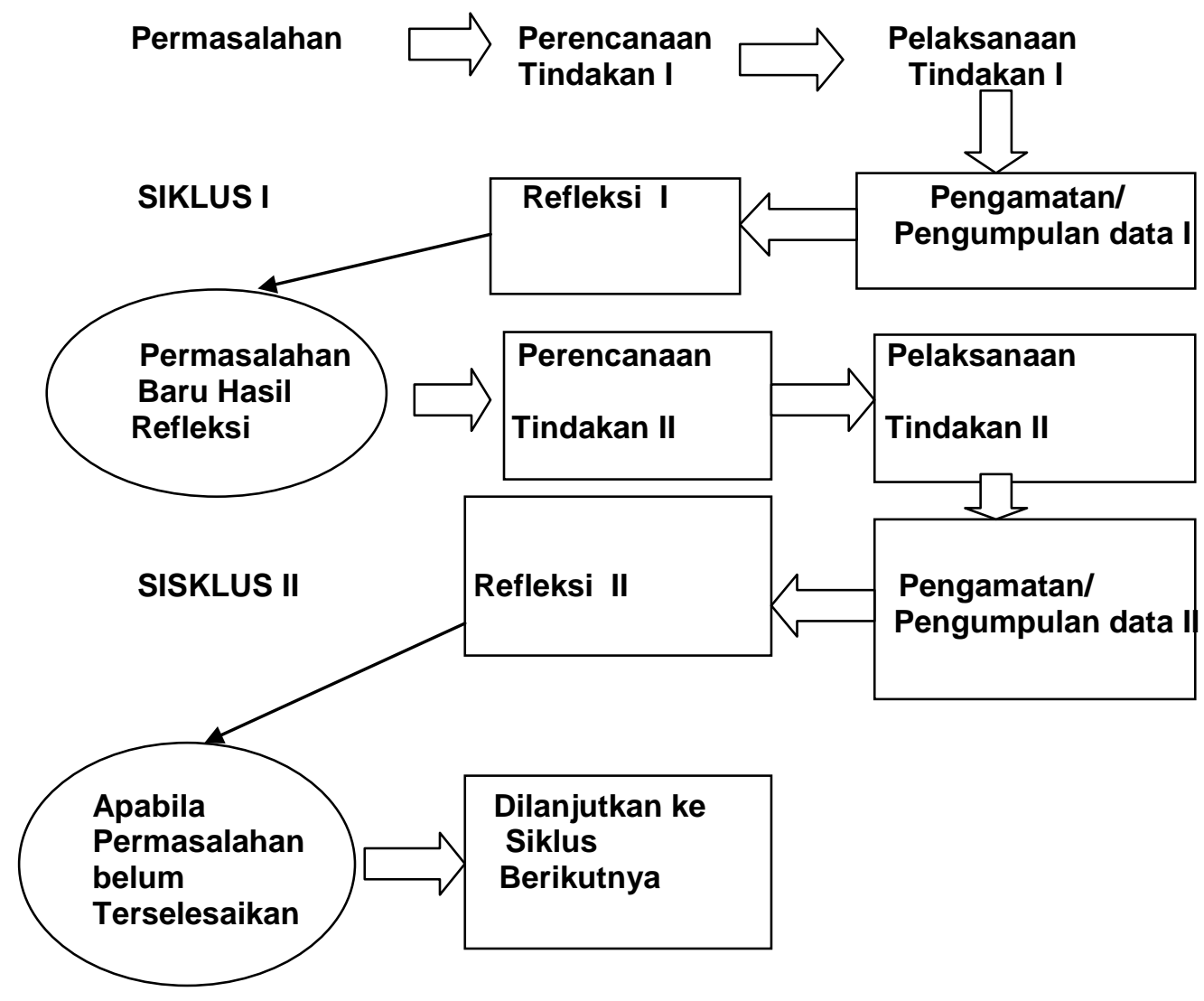

(Suhardjono, $2006: 74$ )

Gambar 1. Prosedur Penelitian 
Penjelasan alur tersebut diatas dapat di paparkan pada bagian berikut ini.

\section{SIKLUS I}

\section{A. Perencanaan}

Pada tahapan ini peneliti/guru membuat rancangan tentang focus permasalahan yang perlu mendapatkan perhatian yaitu :

a. Menyusun kelengkapan administrasi guru termasuk RPP mata pelajaran kimia dan lainnya,

b. Menyiapkan instrumen penelitian untuk guru dan siswa,

c. Menyiapkan format evaluasi pretest dan postest,

d. Menyiapkan sumber belajar yang berupa materi pada mata pelajaran kimia.

e. Mengembangkan scenario pembelajaran dan melakukan koordinasi dengan guru mata pelajaran kimia lainnya.

\section{B. Pelaksanaan}

a. Guru melaksanakan apersepsi, motivasi untuk mengarahkan siswa memasuki materi pelajaran kimia secara koordinatif dan aplikatif menerapkan model pembelajaran Problem Based Learning (PBL), untuk meningkatkan hasil belajar siswa.

b. Guru menjelaskan tujuan pembelajaran yaitu untuk meningkatkan hasil belajar yang akan dicapai, serta kemampuan memaknai materi kimia tentang kimia unsur.

c. Guru menjelaskan materi pelajaran hari itu dan menjelaskan langkah-langkah yang akan dilakukan oleh guru terhadap siswa dalam belajar sehingga hasil belajar mata pelajaran kimia menjadi lebih baik,

d. Guru mendiskusikan kembali dengan seluruh siswa, bila perlu Guru menjelaskan kepada siswa bahwa kemampuan memaknai konsep mata pelajaran kimia memerlukan ketekunan dan kejelian sehingga mampu menerapkannya dalam kehidupan sehari-hari adalah kemampuan yang akan dijadikan bekal hidup kelak

e. Teknik pembelajaran atau metode atau model yang digunakan oleh guru untuk memusatkan perhatian siswa agar siswa merasa di hargai dan terbina suasana yang kondusif, sehingga siswa bebas mengekspresikan atau mengungkapkan tentang apa saja yang ada dalam pikiran, perasaan dan tingkah lakunya untuk mampu merumuskan hasil belajarnya dengan baik.dan benar.

f. Guru mengadakan tes terhadap kemampuan siswa dalam meningkatkan pemahamannya pada materi mata pelajaran kimia tentang kimia unsur.

\section{Pengamatan}

a. Observasi (kolaborasi) mengamati kegiatan guru pada saat pelaksanaan pembelajaran sekaligus pelaksanaan refleksi oleh guru mata pelajaran kimia pada materi yang menjadi pembahasan dalam kegiatan pembelajaran. Pelaksanaan model belajar Problem Based Learning (PBL) dalam pembelajaran dilakukan pengamatan oleh observer melalui pengamatan terhadap sikap dan prilaku siswa dengan menggunakan instrument pengamatan yang telah disiapkan oleh guru. Observer membandingkan hasil pengamatannya dengan melihat perkembangan siswa terhadap hasil belajarnya setelah dilaksanakannya kegiatan pembelajaran secara efektif.

b. Guru mengevaluasi kegiatannya dengan menggunakan angket guru.

\section{Refleksi}

Hasil evaluasi direfleksikan untuk tindakan selanjutnya dengan pembahasan pada hasil observasi, Kekurangan yang terjadi pada siklus I dikaji lebih lanjut dan diperbaiki pada siklus II akan dilaksanakan langkah-langkah yang sama seperti yang dilakukan pada siklus I, namun pelaksanaannya lebih di mantapkan pada komponen-komponen yang belum mencapai hasil maksimal. Sehingga melalui perbaikan tersebut hasilnya akan lebih sempurna.

\section{SIKLUS II}

Pada siklus II Peneliti melakukan tindakan atau refleksi bagi siswa yang belum mencapai hasil maksimal. Kegiatan yang dilakukan pada siklus II sama dengan yang dilakukan pada siklus I (seperti yang telah dijelaskan diatas). Hasil yang dicapai pada siklus II adalah hasil akhir dari proses Penelitian Tindakan Kelas ini. 


\section{Hasil Dan Pembahasan}

Siklus I

Hasil Belajar pada siklus I menunjukkan bahwa pembelajaran mulai efektif dan materi yang disampaikan oleh guru tentang keunikan hutan hujan tropis untuk mata pelajaran biologi melalui penerapan metode pembelajaran eksperimen telah mencapai peningkatan dari prasiklus. Hal ini dibuktikan bahwa 23 orang siswa yang memperoleh nilai diatas KKM dengan katagori tuntas, sedangkan sebanyak 7 orang siswa yang mendapat nilai dibawah KKM dengan katagori belum tuntas. Adapun nilai rata-rata kelas memperoleh angka 78 dengan keberhasilan mencapai $77 \%$. Namun demikian masih perlu dilakukan perbaikan - perbaikan pada siklus II melalui tindakan /refleksi

Pada siklus II

Dengan diterapkannya metode pembelajaran eksperimen secara konsisten dan Peneliti lebih memfokuskan diri dalam pelaksanaan tindakan pada siklus II ini, sehingga mampu meningkatkan hasil belajar siswa dan gairah belajar serta membantu guru dalam melaksanakan pembelajaran biologi secara lebih baik. Peningkatan hasil belajar siswa memperoleh nilai yang lebih baik serta adanya peningkatan perolehan nilai siswa. Hal ini dapat dibuktikan dari hasil nilai yang diperoleh siswa pada siklus II ini adalah sebanyak 30 orang siswa $(100 \%)$ orang siswa yang telah memperoleh nilai diatas KKM dengan kata gori tuntas, sebanyak 30 orang siswa (100\%) siswa yang telah meningkat hasil belajarnya pada siklus II ini. Adapun jumlah nilai rata-rata pada siklus II ini adalah 83 .

Dengan dilakukan refleksi secara maksimal maka pada siklus II telah terjadi peningkatan hasil belajar biologi bagi siswa kelas X. Semester Satu SMA Negeri 1 Sukawati.

Dari data nilai hasil evaluasi siswa kelas X Semester satu SMA Negeri 1 Sukawati, pada siklus II yang telah menunjukkan peningkatan, dan adanya pengaruh yang positif terhadap penerapan metode pembelajaran eksperimen pada mata pelajaran biologi dengan materi keunikan hutan hujan tropis.

Hasil belajar yang masih dibawah target menunjukkan bahwa, proses pembelajaran yang masih kurang aktif dan penerapan metode pembelajaran belum optimal oleh guru. Sedangkan pada siklus II telah menunjukkan peningkatan hasil belajar siswa dan motivasi belajar siswa sudah mulai meningkat dengan adanya peningkatan hasil pembelajaran maka kualitasnya pembelajaranpun telah meningkat.

Setelah dilakukan evaluasi terhadap pelaksanaan Penelitian Tindakan Kelas yang dilaksanakan di SMA Negeri 1 Sukawati pada tindakan proses belajar mengajar mata pelajaran biologi melalui penerapan metode eksperimen secara konsisten yang diajarkan pada siswa kelas $X$ semester satu SMA Negeri1 Sukawati dapat dikatakan berhasil yaitu adanya peningkatan hasil belajar siswai sehingga berdampak terhadap peningkatan mutu pembelajaran .

Kemampuan siswa dalam melakukan proses belajar biologi dengan materi keunikan hutan hujan tropis mengalami peningkatan yang sangat berarti, terutama dalam aktivitas belajar siswa, pemahaman konsep biologi memperoleh hasil yang memuaskan. Dengan diterapkannya metode belajar eksperimen dalam pembelajaran biologi bagi siswa kelas X. SMA Negeri 1 Sukawati mampu meningkatkan hasil belajar secara optimal.

Keseluruhan hasil yang telah dicapai dalam penelitian tindakan kelas ini dapat disajikan dalam tabel dibawah ini.

Tabel 1. Tabel Rekapitulasi Hasil Penelitian Tindakan Kelas Pada Present/Prasiklus, Siklus I, dan Siklus II

\begin{tabular}{clcccl}
\hline \multirow{2}{*}{ No. } & \multirow{2}{*}{ Kreteria } & \multicolumn{3}{c}{ Jenis Tindakan } & \multirow{2}{*}{ Ket. } \\
\cline { 3 - 5 } & Pre test/Prasiklus & S.I & S.II & \\
\hline 1. & Jumlah Nilai & 2177 & 2332 & 2483 & Meningkat \\
\hline 2. & Rata-rata Nilai & 73 & 78 & 83 & Meningkat \\
\hline 3. & Ketuntasan Belajar & $43 \%$ & $77 \%$ & $100 \%$ & Meningkat \\
\hline 4 & $\begin{array}{l}\text { Siswa yang belum } \\
\text { tuntas }\end{array}$ & $57 \%$ & $23 \%$ & $0 \%$ & \\
\hline
\end{tabular}

Hasil penelitian ini sejalan dengan hasil penelitian yang dilakukan oleh Aditya (2015) yang berjudul Pengaruh Metode Eksperimen Terhadap Hasil Belajar Siswa Dalam 
Pembelajaran IPA di Kelas V. Hasil penelitiannya dinyatakan bahwa: Hasil pengujian hipotesis diperoleh4,8138 ( $t_{\text {hitung }}>t_{t a b e l}$ ) sehingga dinyatakan diterima. Dari perhitungan effect size diperoleh 1,5379 (tinggi). Hal ini berarti metode pembelajaran eksperimen memberikan pengaruh yang tinggi terhadap hasil belajar siswa pada pembelajaran IPA di kelas V Sekolah Dasar Negeri 36 Pontianak Selatan.

\section{Simpulan Dan Saran}

Penelitian Tindakan Kelas (PTK), yang dilaksanakan di kelas X Semester satu SMA Negeri 1 Sukawati, telah menghasilkan suatu kesimpulan. Berdasarkan hasil tindakan / refleksi dari siklus I, Siklus II, dapat disajikan kesimpulan bahwa:

1. Penerapan metode pembelajaran eksperimen yang diterapkan dalam pembelajaran mata pelajaran biologi dengan materi keunikan hutan hujan tropis dapat meningkatkan hasil belajar siswa kelas $X$ Semester satu SMA Negeri 1 Sukawati. Hal ini tergambar dari nilai rata-rata hasil yang dicapai siswa pada siklus I mencapai 78 , dengan keberhasilan pembelajaran mencapai $77 \%$, sedangkan siswa yang belum tyuntas mencapai $23 \%$. Walaupun terjadi peningkatan pada siklus I, namun masih perlu dilakukan perbaikan perbaikan pada siklus II karena masih ada sebanyak 7 orang siswa yang belum mencapai ketuntasan belajar mata pelajaran biologidengan materi keunikan hutan hujan tropis.

2. Dari hasil tindakan/refleksi yang dilakukan pada siklus II, maka peningkatan belajar mata pealajaran biologi dengan materi keunikan hutan hujan tropis bagi siswa kelas X SMA Negeri 1 Sukawati di semster satu, dapat dicapai secara optimal. Hal ini tergambar dari ratarata nilai pada siklus II mencapai 83 dengan keberhasilan npembelajaran mencapai $100 \%$.

Dengan demikian penerapan metode pembelajaran eksperimen dalam pelajaran biologi dengan materi keunikan hutan hujan tropis ternyata tepat dan hasil belajar siswa dapat meningkat. Peningkatan hasil belajar siswa dapat dicapai dari siklus I, siklus II sesuai dengan harapan Peneliti.

Setelah melaksanakan penelitian dan melihat hasil yang dicapai, maka peneliti menyarankan sebagai berikut : 1) Disarankan agar guru SMA Negeri 1 Sukawati pada umumnya dan guru biologi pada khususnya dapat mengembangkan strategi pembelajaran dengan konsisten sesuai dengan mata pelajaran yang diajarkannya, 2) Untuk memberikan pengalaman nyata kepada siswa dalam pembelajaran disarankan dapat menerapkan latihan latihan dengan melakukan percobaan atau eksperimen terhadap materi yang dipelajarinya, 3) Metode belajar eksperimen terbukti mampu meningkatkan hasil belajar siswa pada mata pelajaran biologi, untuk itu disarankan dapat dipertahankan dan terus dilaksanakan dalam pembelajaran, 4) Kepada para siswa agar terus meningkatkan semangat belajar biologi demikian juga pada mata pelajaran lainnya untuk mencapai prestasi belajar yang tinggi, dan 5) Hasil Penelitian Tindakan Kelas ini dapat dijadikan refrence bagi guru yang akan melakukan kegiatan serupa.

\section{Daftar Pustaka}

Aditya, Putri, Rosnita dan Syamsiati. 2015. Pengaruh Metode Eksperimen Terhadap Hasil Belajar Siswa Dalam Pembelajaran IPA di Kelas V. Jurnal Pendidikan dan Pembelajaran Volume 4 Nomor 9. UNTAN.

Alfi ,Sulasfiana (2018). dentifikasi Materi Biologi SMA Sulit Menurut Pandangan Siswa Dan Guru SMA Se-Kota Salatiga. Journal of Biology Education Vol 1 No 2 (2018)

Arikunto, Suharsimi, 1989, Penilaian Program Pendidikan, Proyek Pengembangan LPTK Depdikbud, Dirjen Dikti.

Arikunto, Suharsimi, 1993, Manajemen Mengajar Secara Manusiawi, jakarta rineksa Cipta.

Basiran, Mokh. 1999. Apakah yang Dituntut GBPP Bahasa Indonesia Kurikulum 1994 ?. Yogyakarta: Depdikbud.

Degeng, I.N.S. 1997. Strategi Pembelajaran Mengorganisasi Isi dengan Model Elaborasi. Malang: IKIP dan IPTDI. 
Hidayat ,Ara (2017). Penerapan Model Pembelajaran Predict-Observe-Explain (Poe) Terhadap Hasil Belajar Siswa Pada Materi Sistem Indera Manusia Di Sman 3 Kota Cimahi Tahun Pelajaran 2017/2018 . Jurnal Pendidikan Biologi 2017.

Garnasih ,Tuti (2018). Peningkatan Motivasi Dan Hasil Belajar Siswa Melalui Pembelajaran Di Lingkungan Sekolah Pada Materi Keanekaragaman Hayati Di Kelas X-Mia Mas ArRosyidiyah . Jurnal Program Studi Pendidikan Biologi (Februari), Vol. (8), No.(1).

Imam Syafi'e. 1993. Terampil Berbahasa Indonesia I. Jakarta: Departemen Pendidikan dan Kebudayaan.

Moeleong, Lexy J. 2000. Metodologi Penelitian Kualitatif. Bandung: PT. Remaja Rosyda Karya.

Nurkholis (2013). Pendidikan Dalam Upaya Memajukan Teknologi . Jurnal Kependidikan, Vol. 1 No. 1 Nopember 2013.

Rahmayanti ,Vina (2016). Pengaruh Minat Belajar Siswa Dan Persepsi Atas Upaya Guru Dalam Memotivasi Belajar Siswa Terhadap Prestasi Belajar Bahasa Indonesia Siswa Smp Di Depok . Jurnal SAP Vol. 1 No. 2 Desember 2016 ISSN: 2527-967X.

Setyanto ,Eko (2015). Memperkenalkan Kembali Metode Eksperimen dalam Kajian Komunikasi . Jurnal IImu Komunikasi Volume 3, Nomor 1, Juni 2065: 37 - 48.

Sudarisman ,Suciati (2015). Memahami Hakikat Dan Karakteristik Pembelajaran Biologi Dalam Upaya Menjawab Tantangan Abad 21 Serta Optimalisasi Implementasi Kurikulum 2013 . Jurnal Florea Volume 2 No. 1, April 2015 (29-35). 